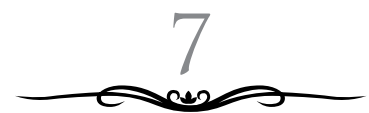

\title{
STRATEGI MELESTARIKAN PEMANFAATAN KOLEKSI REFERENSI CETAK DI TENGAH MARAKNYA BERBAGAI MACAM REFERENSI ONLINE DENGAN SEGALA KEMUDAHANNYA
}

\author{
Yanuastrid Shintawati dan Hairul Agust Cahyono \\ Universitas Wijaya Kusuma, Surabaya, Indonesia \\ dan STAIN, Pamekasan, Jawa Timur, Indonesia \\ Email : yanuastrid@yahoo.com
}

\begin{abstract}
The development of information technology in this globalisation era make the information publix that live inside get the convenience to easily search, find and get information almost in all respects. This impacted on the existence of a reference collection which was originally a reference to help information seekers find information about certain information may be eroded over time due to the emergence of media presence online references. The difficulty in using several reference collections such as dictionaries, directory, ensiclopedy, map etc. inversely proportional to the ease offered by products launched by companies such as Google, Yahoo, AltaVista and Lycos. The role of librarians and lecturers demanded participation in preserving cultural read while maintaining general collection and the reference collection especially prints to prevent the existence of a reference collection can still be maintained and also still be mainyained and also still be used in addition to the reference media online.
\end{abstract}

Keyword: Reference collection, online reference collection 


\begin{abstract}
Abstrak
Perkembangan teknologi informasi di era globalisasi dewasa ini membuat masyarakat informasi yang hidup di dalamnya mendapatkan kemudahan kemudahan dalam mencari, menemukan dan memperoleh informasi hampir di segala hal. Hal ini berdampak pula pada keberadaan koleksi referensi yang semula menjadi acuan dalam membantu pencari informasi menemukan informasi informasi tertentu lama kelamaan mungkin tergerus keberadaannya karena kemunculan media referensi online. Kesulitan dalam menggunakan beberapa koleksi referensi seperti kamus, direktori, esiklopedia, peta dan lain sebagainya berbanding terbalik dengan kemudahan yang ditawarkan oleh produk produk yang diluncurkan oleh perusahaan seperti Google, Yahoo, Altavista dan Lycos. Peran pustakawan dan dosen dituntut partisipasinya dalam tetap menjaga melestarikan budaya membaca koleksi umum dan khususnya koleksi referensi tercetak agar keberadaan koleksi referensi tetap dapat dipertahankan dan juga tetap dimanfaatkan di samping media referensi online.
\end{abstract}

Keyword: Koleksi referensi, koleksi referensi online

\title{
A. Pendahuluan
}

Perkembangan teknologi informasi di era gloalisasi dewasa ini membuat masyarakat informasi yang hidup di dalamnya mendapatkan kemudahan kemudahan dalam mencari, menemukan dan memperoleh informasi hampir di segala hal. Kemudahan kemudahan itu dapat diketemukan dengan cara mengakses internet yang menyuguhkan informasi mengenai segala hal melalui berbagai produk yang disediakan oleh perusahan perusahaan yang menyediakan jasa dan layanan internet. Banyak perusahaan yang menyediakan produk dan jasa layanan internet namun bisa disebutkan antara lain Google, Yahoo, Altavista, My Excite, dan masih banyak lagi. Perusahaan jasa layanan internet ini meluncurkan produk produknya yang membuat pencari informasi dapat dengan cepat dan akurat menemukan informasi yang diinginkan. Jasa layanan internet untuk menjembatani kesulitankesulitan pencarian informasi dalam segala hal, tak terkecuali dalam pencarian informasi berhubungan dengan hal hal yang sebelum adanya internet harus dicari dengan bantuan buku buku referensi semisal kamus, direktori, ensiklopedia, peta dan masih banyak lainnya. 
Buku buku referensi ini dibuat sesuai dengan fungsi dan kegunaannya yaitu membantu menemukan informasi yang diinginkan. Buku buku referensi ini memiliki karakteristik dan cara pemanfaatannya masing masing. Seperti yang dikatakan Saleh, Abdul Rahman, dan Mustafa, Badollah. menyatakan koleksi bahan rujukan merupakan koleksi yang terdiri atas buku-buku atau bahan pustaka lainnya, yang memuat informasi mengenai hal tertentu. Koleksi tersebut dianggap sangat bermanfaat karena dapat digunakan sebagai rujukan atau acuan dalam hal memberi jawaban terhadap pertanyaan yang mereka hadapi. ${ }^{1}$ Beberapa koleksi referensi mungkin sudah tidak asing bagi mereka yang bergerak di dunia kepustakawanan, namun mungkin asing bagi masyarakat awam. Kalau jenis jenis koleksi referensi ini kita tanyakan kepada orang yang jarang atau bahkan tidak pernah mempergunakannya dalam kehidupan mereka tentu mereka akan menjawab tidak tahu namun coba bandingkan dengan misalnya mereka yang memiliki handphone yang terkoneksi dengan internet, maka apabila mereka kesulitan untuk menemukan sebuah alamat mereka akan dengan cepat menggunakan layanan google map untuk memudahkan menemukan alamat tersebut padahal sebelum ada google map orang masih menggunakan peta. Dengan semakin berkembangnya teknologi informasi semakin memudahkan orang orang untuk menemukan alamat tidak perlu menggunakan peta atau direktori namun hanya dengan membuka google map tempat tersebut bisa diketemukan lengkap dengan rute jalan menuju ke tempat itu bahkan juga dengan jam buka dan tutup tempat tersebut.

Alangkah sangat dimudahkan masyarakat yang hidup di era teknologi informasi yang semakin canggih ini. Yang menjadi pertanyaan atau mungkin sebuah kekhawatiran akankah generasi mendatang nanti tidak akan mengenal dan mampu membaca peta, membaca atlas, menemukan alamat dengan direktori, mencari arti kata dengan kamus dan masih banyak lagi. Mereka akan dengan cepat melupakan karya karya referensi cetak tersebut dan beralih menggunakan kemudahan kemudahan yang dihadirkan oleh teknologi informasi. Sebagai

${ }^{1}$ Saleh, Abdul Rahman., dan Mustafa, Badollah. Bahan Rujukan. Jakarta: Universitas Terbuka, 2010. 
orang orang yang bergerak di dunia kepustakawanan haruskah kita berdiam diri atau tetap mempertahankan cara cara lama kita dalam memperoleh informasi informasi dan memberikan contoh kepada anak didik kita untuk terus belajar menggunakan koleksi referensi dengan bijak. Fenomena di atas bukan menjadi hal baru lagi di dunia kepustakawanan dan teknologi, tulisan ini merupakan sebuah wacana bagi penulis dalam mengkaji kekhawatiran akan hilangnya budaya membaca koleksi tercetak.

\section{B. Pembahasan}

\section{Koleksi Referensi}

Koleksi referensi menurut Sumarji dalam Rahayuningsih adalah kumpulan atau kelompok koleksi pustaka yang terdiri dari bahan bahan pustaka berisi karya karya yang bersifat memberitahu/ menunjukkan mengenai informasi informasi tertentu, yang disusun secara sistematis (biasanya secara alfabetis) untuk digunakan sebagai alat penunjuk atau konsultasi. ${ }^{2}$

Jadi pada dasarnya koleksi referensi dimaksudkan untuk membantu orang dalam menemukan informasi yang memerlukan bantuan atau acuan serta memberikan jawaban atas pertanyaan pertanyaan kebutuhan pemustaka. Dalam tulisan ini penulis membedakannya menjadi tercetak dan online.

\section{a. Koleksi Referensi Cetak}

Beberapa koleksi referensi tercetak yang digunakan sebagai acuan atau media dalam menemukan informasi antara lain :

1) Sumber Geografi

Geografi adalah ilmu pengetahuan yang mengamati, memelajari, menganalisa, dan menghubungkan perbedaan daerah daerah di permukaan bumi. Sumber sumber ilmu bumi yang dapat dikategorikan sebagai koleksi referensi antara lain : Gazeteer, buku petunjuk/guidebook, atlas, dan globe. ${ }^{3}$ Sedangkan sumber

${ }^{2}$ Rahayuningsih, F. Pengelolaan Perpustakaan. Yogyakarta: Graha Ilmu, 2007. Hlm. 105.

3 Lasa. Kamus kepustakawanan indonesia. Pustaka book publisher: Yogyakarta, 2009. Hlm.91 
geografi merupakan bahan pustaka yang memuat informasi mengenai tempat, gunung, sungai, batas negara, batas wilayah, dan sebagainya yang berkaitan dengan lokasi yang disajikan dalam bentuk peta, atlas, globe, gazeteer, dan buku petunjuk perjalanan.

Cara penelusuran : informasi dicari berdasarkan urutan wilayah negara, provinsi dan sebagainya.

2) Direktori atau Buku Petunjuk.

Pertanyaan tentang nama, alamat, nomor telepon dan data pribadi lain seseorang atau organisasi sering kali dibutuhkan oleh masyarakat suatu waktu, direktori digunakan untuk menjawab pertanyaan tentang data tersebut di atas. direktori merupakan jenis buku yang termasuk sebagai buku rujukan yang berisi daftar nama, orang (pejabat), lembaga, badan, organisasi yang dilengkapi dengan alamat, kegiatan, kode, dan data lain yang disusun secara alfabetis dan sistematis atau urutan kode kode nomor. $^{4}$

Sesuai dengan definisinya, maka direktori digunakan untuk mencari informasi tentang:

a. Alamat atau nomor telepon, tentang seseorang atau perusahaan atau instansi.

b. Nama lengkap seseorang, perusahaan atau organisasi atau instansi.

c. Keterangan mengenai instansi atau mengenai produk pabrik tertentu atau pelayanan suatu biro jasa tertentu.

d. Keterangan tentang siapa yang menjadi kepala suatu instansi, direktur suatu perusahaan, rektor suatu perguruan tinggi, kepala sekolah dan sebagainya pada saat ini atau pada suatu periode tertentu.

Direktori/buku petunjuk dapat dibagi dalam beberapa golongan sebagai berikut:

4 Suwarno, Wiji. Perpustakaan dan Buku : Wacana Penulisan dan Penerbitan. Jogjakarta:Ar-ruzz Media, 2011. Hlm. 65. 
a. Buku petunjuk yang bersifat lokal, misalnya buku telepon, petunjuk kota dan sebagainya.

b. Buku petunjuk yang berhubungan dengan pemerintah, misalnya petunjuk tentang kantor pos, kantor polisi dan instansi-instansi pemerintah lainnya. Buku petunjuk pada kelompok ini sering juga memuat informasi tentang badanbadan internasional.

c. Buku petunjuk yang memuat informasi tentang badan-badan instansi, misalnya sekolah, yayasan, perpustakaan, rumah sakit, museum dan organisasi lain yang sejenis.

d. Buku petunjuk tentang suatu profesi, misalnya ahli hukum, ahli perpustakaan, dokter, dan sebagainya.

e. Buku petunjuk yang memuat informasi tentang perdagangan dan industri, misalnya pabrik, perusahaan, biro jasa, dan lain-lain.

3) Ensiklopedi

Ensiklopedi merupakan bahan rujukan yang berisi uraian ringkas tentang berbagai topik atau subyek yang umumnya disusun secara alfabetis, kadang-kadang disertai deskripsi, definisi, dan informasi bibliografis. Menurut Yusup ensiklopedia adalah daftar istilah istilah ilmu pengetahuan berikut keterangan ringkasnya. Ensiklopedia menampung semua topik atau istilah tentang fakta atau peristiwa, bahkan hampir dapat menjawab semua pertanyaan mengenai apa, siapa, bagaimana, dan kapan, serta di mana suatu peristiwa terjadi kecuali hal hal atau fakta yang bersifat aktual dan mutakhir yang belum disempat direkamnya. ${ }^{5}$ Saat ini berbagai ensiklopedi disusun dengan berbagai tujuan, tetapi intinya adalah untuk mengumpulkan dan mengorganisir pengetahuan yang tersebar di berbagai belahan dunia, atau untuk memenuhi kebutuhan informasi para pembaca. Hampir semua bidang pengetahuan dan informasi dikupas, dirinci dan dijelaskan melalui berbagai artikel yang disusun secara detail dan didukung oleh fakta-fakta yang

5 Yusuf, pawit M. Pedoman praktis mencari informasi. Bandung:PT Remaja Rosdakarya, 1995.Hlm.37 
akurat. Ensiklopedia dapat berupa satu jilid maupun lebh dari jilid tergantung banyaknya informasi yang dicantumkan. Ilmu pengetahuan pada ensiklopedi dapat berupa informasi bidang khusus, jika ensiklopedi di bidang khusus maka informasi tersebut membahas tentang informasi tertentu.

Contoh ensiklopedi khusus :

Ensiklopedi Hukum Islam. Jakarta: PT. Ichtiar Baru Van Hoeve. Pada Ensiklopedi Hukum Islam ini membahas tentang dua aspek besar dalam ajaran Islam yaitu syariat dan fikih, pada ensiklopedia dibagi menjadi 6 jilid.

Cara menelusur : dalam ensiklopedi yang hanya terdiri dari satu jilid, entri-entri dapat langsung dicari di bawah abjadnya, kemudian ke halaman yang memuat running title, sedangkan pada ensiklopedi yang terdiri atas beberapa jilid, penelusurannya akan lebih efektif bila dilakukan melalui indeks di mana entrientrinya merujuk ke nomor jilid serta nomor halaman.

4) Kamus

Kamus adalah buku acuan yang memuat kata, ungkapan, dan istilah atau nama biasanya disusun menurut abjad berikut keterangan tentang makna pemakaian, atau terjemahannya. ${ }^{6}$ Banyak manfaat yang dapat diperoleh dari kamus sebagai :

a. Tempat mencari makna kata.

b. Tempat memeriksa ejaan, penyukuan, serta penggunaan tanda hubung.

c. Tempat mencari lafal kata.

d. Tempat mencari riwayat, asal-usul dan turunan kata.

e. Tempat mencari sinonim, antonim, dan homonim kata.

f. Tempat mencari singkatan, akronim, tanda dan lambang kata.

g. Tempat mencari kata asing yang sering dipakai.

${ }^{6}$ Departemen pendidikan nasional. Kamus besar bahasa indonesia pusat bahasa. PT. Gramedia Pustaka Utama: Jakarta, 2008. Hlm. 614. 
Cara penelusuran : entri-entri yang terdapat dalam kamus, dapat langsung ke abjad kemudian merujuk ke halaman di mana kata tersebut berada.

\section{b. Media referensi online}

Media online dewasa ini memang memberikan kemudahan dan kenyamanan bagi para penggunanya. Teknologi informasi yang semakin canggih dan juga dukungan dari bermacam macam perusahaan yang bergerak dalam bidang jasa dan layanan internet menjadikan masyarakat dengan mudah dan cepat dapat menemukan berbagai macam informasi yang mereka inginkan. Kemudahan ini yang populer dengan istilah akses menuju media online dan akses media online tergantung pada alamat web yang kita inginkan

Alamat web merupakan sebuah tempat pencarian yang sering digunakan untuk mencari suatu informasi yang kita inginkan. dalam pencarian informasi dengan koleksi referensi pada perpustakaan sekarang bisa diakses melalui referensi online di antaranya adalah :

1) Kamus Online

Ada beberapa kategori kamus salah satunya adalah kamus bahasa dan kamus dwibahasa. Kamus bahasa yang artinya kamus yang disusun berdasarkan kategori tatabahasanya, jenisnya, etimologis dan aneka macam artinya. ${ }^{7}$ Kalau pada kamus tercetak pemustaka menghadapi kamus secara fisik berbeda dengan kamus online yang dapat diakses melalui internet pada komputer maupun handphone kapanpun dan di manapun. Kamus online ini dapat diakses pada alamat web http://kbbi. web.id/ dan http://kamusbahasaindonesia.org/

Translate atau terjemahan menurut Kamus Bahasa Indonesia adalah menyalin (memindahkan) suatu bahasa ke bahasa yang lain atau mengalihbahasakan. ${ }^{8}$ Alamat web yang dapat diakses di antaranya https://translate.google.co.id/?hl=id dan http:// sederet.com/

7 Lasa. Kamus kepustakawanan indonesia. Pustaka book publisher: Yogyakarta, 2009. Hlm. 133

${ }^{8}$ Departemen pendidikan nasional. Kamus besar bahasa indonesia pusat bahasa. PT. Gramedia Pustaka Utama: Jakarta, 2008. Hlm. 1425 
Translate online merupakan layanan yang disediakan untuk menerjemahkan bagian teks dalam satu bahasa ke bahasa lain. Kegunaan translater jika suatu saat anda membutuhkan jasa penerjemahan untuk tulisan maka translater online bisa membantu anda. Siapa tau anda ingin menjadi proffesional blogger dan menulis artikel ke dalam bahasa lain anda menggunakan google translate untuk membantu anda atau mungkin mengerjakan tugas dari dosen kepada mahasiswa untuk menerjemahkan buku pegangan dari bahasa Inggris ke dalam bahasa Indonesia translater online akan banyak dipilih untuk membantu mahasiswa mahasiswa ini.

2) Ensiklopedia online

Pada zaman sekarang perkembangan tekhnologi sangat pesat sekali yang dibarengi peradaban manusia yang bertambah maju. Semakin majunya tekhnologi informasi maka perkembangan informasi juga semakin bertambah. Oleh karena itu diperlukan sarana pendukung untuk mempermudah pencarian informasi itu sendiri. Pada saat ini ICT (Information Communication Technology) menyajikan banyak sekali informasi yang dapat diunduh dalam bentuk digital dan dapat diakses baik dalam bentuk CD ( Compact Disc) maupun melalui akses internet. Ensiklopedia pada saat ini juga bisa diakses melalui internet, malah akses pencariannya lebih singkat yang dapat ditelusuri dengan cara penelusuran (search). Dalam mengakses melalui internet dapat dilakukan pada komputer maupun handphone yang terkoneksi pada jaringan internet. Alamat ensiklopedia yang dapat diakses melalui internet salah satunya adalah http:// www.wikiwand.com/ms/, http://www.wikipedia.com dan http:// id.islam.wikia.com/wiki/.

3) Google Maps

Google Maps merupakan akses yang dapat menunjukkan arah jalan yang kita tuju dengan menunjukkan arah yang diinginkan. Tak hanya itu, google map mampu menujukkan lokasi di mana kita berada sehingga orang dengan mudah mengetahui tempat 
kita atau istilahnya adalah locater ${ }^{9}$. Aplikasi google map telah merajai aplikasi dalam melihat dunia secara mudah. Kita bisa melihat bagian-bagian dari dunia di berbagai negara dengan cukup menakjubkan. Alamat web pada google map yaitu https:// www.google.co.id/maps/

4) Google Search

Google Search ${ }^{10}$ merupakan mesin pencarian informasi, segala informasi yang kita perlukan akan dapat tercukupi dengan mengakses google search apalagi bila dalam komputer maupun handphone kita sudah memiliki aplikasi google search yang membuat google search seperti dalam genggaman kita. Google Search terus mengalami perubahan demi kenyamanan penggunanya dalam mencari data dan informasi baik berupa artikel maupun gambar dengan cepat dan beragam referensi. Jika dibandingkan dengan search engine lainnya memang saat ini google search yang terbaik dengan kualitas data serta keragaman informasi yang cepat dan banyak. Alamat web yang dapat diakses adalah www.google.com

5) Google Earth

Aplikasi google earth menjadi salah satu yang terbaik dalam melihat kondisi bumi di seluruh dunia. Bahkan saat ini google earth dapat menampilkan dunia bawah laut. seperti hal nya Google map. Google menyebutnya Geotagging yakni cara menghubungkan informasi ke lokasi dunia nyata. Anda melihat informasi geotag pada peta. Google Earth ${ }^{11}$ memberikan pengguna pilihan, dari melihat citra satelit dari planet ke peta overlay, tiga dimensi dan fitur medan cityscapes. Google Earth juga memungkinkan pengembang untuk membuat aplikasi untuk menghubungkan informasi ke lokasi tertentu di dunia. Pengguna dapat memilih untuk melihat informasi geotag mulai

9 . Yusuf M. Pawit. Teori dan Praktek Penelusuran Informasi : Information Retrieval. Jakarta:Kencana Prenada Media Grup. 2010.Hal. 204

10 . Yusup M. Pawit. Teori dan Praktek Penelusuran Informasi : Information Retrieval. Jakarta: Kencana Prenada Media Grup. 2010. Hal.:294.

11 Yusup. M. Pawit. Teori dan Praktik Penelusuran Informasi : Information Retrieval. Jakarta: Kencana Prenada Media Grup. 2010. Hal. 308. 
dari laporan berita umum dengan data yang disesuaikan. Google Earth memungkinkan untuk menggambarkan berita dengan cara yang baru. Sebagai contoh, sebuah kantor berita bisa menggambarkan cerita tentang kebakaran hutan dengan memplot daerah kerusakan pada Google Earth. Alamat web yang dapat diakses adalah https://www.google.com/earth/

\section{Menilai Koleksi Referensi Cetak}

Koleksi referensi tercetak seperti contoh contoh yang telah disebutkan di atas, dalam menggunakan atau membaca koleksi tersebut untuk memperoleh sebuah informasi memang diperlukan suatu keahlian khusus yang dapat diperoleh secara mandiri maupun dengan bersungguh sungguh mempelajarinya seperti contohnya pada satu mata kuliah di perguruan tinggi yaitu Layanan Referensi. Dalam mata kuliah ini mahasiswa atau peserta didik diberikan pemahaman mengenai definisi, fungsi dan manfaat dari koleksi referensi tersebut.

Dosen mengajarkan bagaimana membaca koleksi referensi ini, dalam proses pengajaran memang dibutuhkan suatu pemahaman mengenai karakteristik dari koleksi tersebut. Misalnya kamus, dari definisinya kamus adalah bahan referensi yang berisi daftar kata kata yang disertai maknanya. Untuk menemukan arti kata "media" kita akan mencari dengan mengacu kepada huruf "m" karena kamus disusun secara alfabetis. Demikian pula dengan misalnya kita harus mencari informasi mengenai "kapan gunung krakatau meletus?" maka kita akan mencarinya dengan menggunakan Ensiklopedia Indonesia yang fungsinya memang menyediakan berbagai macam informasi mengenai apapun termasuk kejadian kejadian yang terjadi di Indonesia. Untuk menemukan informasi kapan gunung krakatau meletus kita akan merujuk pada ensiklopedia pada jilid ke sekian dan merujuk lagi ke deretan huruf G karena ensiklopedia disusun secara alfabet. Memang agak sulit bagi orang awam untuk menemukan informasi informasi dengan menggunakan koleksi koleksi rujukan semisal kamus dan ensiklopedia tersebut. Belum lagi kalau memang orang yang mencari informasi tersebut awam mengenai peta, ensiklopedia, direktori dan media pencari informasi yang lain. Langkah langkah dalam menelusur 
dan metode pencariannya menyulitkan bagi orang yang tidak terbiasa menggunakan koleksi koleksi rujukan semacam ini, karena harus merujuk kepada urutan alfabet, kemudian merujuk ke halaman di mana informasi tersebut dimuat. Proses pencarian informasi semacam ini kadang membuat orang orang tidak sabar dan tidak telaten melakukannya, sehingga dalam mengakses koleksi referensi tercetak dibutuhkan faktor penunjang dari dua (2) hal yaitu dari faktor individu pencari informasi dan dari faktor sumber informasinya sendiri berikut penjelasannya :

\section{a. Faktor individu pencari informasi}

Berkaitan dengan kemampuan seseorang untuk bisa mengakses pencarian informasi dari koleksi referensi tercetak adalah sebagai berikut :

1. Harus mengenali terlebih dahulu jenis dan karakteristik masing masing koleksi referensi misalnya apakah disusun secara alfabetis seperti kamus atau secara sistematis kronologis seperti ensiklopedia.

2. Harus tahu atau familier terlebih dahulu dengan urutan alfabetis, berkaitan dengan pencarian informasi menggunakan urutan alfabet sehingga pengakses harus mengerti alfabet sehingga tidak terbalik balik.

3. Harus mengetahui kegunaan dan manfaat masing masing koleksi referensi.

4. Berkaitan dengan fungsi dan kegunaan masing masing koleksi, misalnya kamus fungsinya untuk mencari arti kata, sedangkan direktori fungsinya untuk mencari alamat kantor perusahaan atau alamat alamat yang lain.

\section{b. Faktor sumber informasi (koleksi referensinya) :}

1. Otoritasnya

Penanggung jawab secara materi intelektual dari suatu koleksi referensi harus bisa dipertanggungjawabkan, jangan sampai penulis atau penanggungjawab intelektual adalah orang atau lembaga yang tidak terpercaya. 
2. Kemutakhiran

Tingkat kemutakhiran suatu koleksi referensi juga menjadi pertimbangan dalam menemukan informasi. Semakin mutakhir suatu koleksi semakin dapat dipercaya untuk digunakan sebagai referensi.

3. Susunan entri

Kebanyakan koleksi referensi disusun secara alfabet sehingga memudahkan dalam menemukan sebuah informasi.

- Merupakan kelebihannya.

a. Tidak membutuhkan alat elektronik untuk membuka kontennya walaupun dibuat secara elektronik.

b. Tidak memiliki ketergantungan kepada listrik

c. Tidak memiliki ketergantungan kepada konektivitas jaringan internet.

- Merupakan kekurangannya

a. Penggunaan kamus cetak cukup sulit karena mahasiswa harus berulang kali membuka kamus dan tulisannya bisa dikatakan sulit dibaca karena terlalu kecil hurufnya.

b. Memiliki usia yang terbatas. Koleksi referensi tercetak tidak dapat kita simpan sepanjang waktu, pasti ada usianya. Kerusakan koleksi referensi ter cetak di antaranya disebabkan oleh: faktor alam seperti lembab, air, suhu, atau pun karena faktor manusia yang lalai dalam merawatnya.

c. Tidak efisien membawa buku buku rujukan dalam jumlah yang banyak. Ya, salah satu yang membuat jengkel kita adalah ketika kita harus membawa banyak buku rujukan, baik sekedar memindahkannya maupun ketika kita membutuhkan membacanya bergantian untuk suatu waktu misalnya dalam perjalanan atau di tempat lain.

d. Kesulitan dalam mendistribusikannya. Buku buku rujukan secara umum hanya dapat dibeli melalui distribusi toko buku konvensional yang tidak selalu ada di berbagai kota. Bahkan untuk daerah-daerah pelosok hal ini menjadi 
kendala yang sangat menyulitkan bagi penyebaran buku rujukan/referensi.

\section{Menilai Koleksi Referensi Online}

Mari sekarang kita membahas menemukan informasi dengan menggunakan media referensi online. Seperti sudah dicontohkan di atas produk produk yang dikeluarkan oleh Google memberikan kemudahan dan kenyamanan orang dalam menemukan informasi yang mereka inginkan. Google map, aplikasi yang diluncurkan oleh google menggusur pemakaian peta cetak yang untuk membawa dan membukanya membutuhkan waktu dan konsentrasi yang tinggi, namun dengan google map orang akan dengan mudah menemukan tempat tempat dan jalan menuju ke tempat yang diinginkan dengan mengetik lokasi awal di mana kita berada dan mengetik tempat tujuan, maka dengan cepatnya rute jalan akan terpampang di gadget kita lengkap dengan estimasi durasi waktu untuk mencapai tempat tersebut.

Dahulu kita menggunakan kamus bahasa untuk membantu kita dalam menerjemahkan tulisan kita ke dalam bahasa Inggris misalnya, menggunakan kamus kita harus membolak balik halaman demi halaman untuk menemukan terjemahan dari setiap kata yang kita maksudkan, namun di era teknologi informasi yang serba canggih ini kita tidak perlu repot repot membuka halaman halaman kamus bahasa kita hanya perlu membuka Google translate dan hebatnya kita bisa memasukkan sejumlah kata ke dalam mesin penterjemah google dan dalam sekejap tulisan bahasa Indonesia kita sudah berubah menjadi tulisan dalam bahasa Inggris. Begitulah kemudahan kemudahan yang diberikan oleh media referensi online semakin memanjakan kita dari hari ke hari.

Seperti dari koleksi referensi tercetak demikian juga dengan media referensi online, ada beberapa hal yang harus dicermati baik dari cara mengakses maupun kualitas informasi yang dihasilkannya, berikut adalah penjelasannya:

1. Salah satu motif seseorang melakukan kegiatan pencarian informasi adalah kemudahan dan kecepatan teknologi informasi yang mendukungnya. Dari segi kemudahan 
mengakses informasi tidak diperlukan waktu yang lama, bahkan dapat dikatakan singkat serta murah dilihat segi biaya.

2. Keabsahan data dari media referensi online. Mencermati keabsahan data dari media referensi online sebenarnya sama dengan mencermati otoritas media referensi cetak, namun ada beberapa kesulitan yaitu seperti tidak adanya indikasi dari penerbit.

3. Tingkat kemutakhiran pada media ini mungkin lebih unggul karena dapat direvisi dengan cepat.

4. Yang merupakan kelebihan koleksi referensi online :

a. Bisa dibawa kemana-mana tanpa memberatkan, koleksi koleksi referensi sekalipun bisa disimpan dalam sebuah tablet atau smartphone.

b. Mencarinya gampang karena tidak mungkin tercecer, terselip, dan sebagainya, selalu siap dalam tablet atau laptop.

c. Tidak menjadi usang atau rusak, selalu dalam kondisi rapi dan jelas sekalipun sudah berumur puluhan tahun. Bahkan saat tablet rusak pun, bisa diunduh ulang di tablet pengganti

d. Dapat menghemat waktu dan tempat, kita dapat menghemat waktu kita karena kita tidak perlu ke perpustakaan atau ke toko buku untuk meminjam atau membelinya, dari sedi tempat kita tidak memerlukan rak untuk penyimpanannya seperti pada koleksi referensi cetak.

e. Lebih mudah didapatkan, hanya dalam jangka waktu beberapa menit dengan mengunduh aplikasinya.

Seperti pendapat Winkler mengenai salah satu koleksi referensi online yaitu kamus elektronik ${ }^{12}$

"Dictionaries in computerised form are one of the latest developments in the field of lexicography. They offer many of the advantages of modern technology, contain much more information than the printed versions on which they are based,

12 Winkler, Birgit. 2001. English Learner's Dictionaries on CD ROM as Reference Language and Learning Tools. Journal Cambridge 13(2) : 191. 
can make use of multimedia, such as sound and animation, and perform complex searches much faster than we can turn pages".

"Kamus dalam bentuk komputerisasi adalah salah satu perkembangan terbaru dalam bidang leksikografi. Mereka menawarkan banyak keuntungan dari teknologi modern, berisi informasi jauh lebih banyak daripada versi cetak yang mereka didasarkan, dapat menggunakan multimedia, seperti suara dan animasi, dan melakukan pencarian kompleks jauh lebih cepat dari yang kita bisa mengubah halaman «.

5. Merupakan kekurangan dari referensi online :

a. Tampilannya kalah besar dibanding koleksi referensi tercetak yang begitu besar. Akibatnya harus merubah tampilan untuk mendapatkan hasil gambaran yang maksimal.

b. Tidak dapat dipinjamkan kepada teman, tetangga, apalagi orang lain yang tidak dikenal.

c. Membutuhkan suatu perangkat lunak atau aplikasi untuk membukanya sedangkan koleksi referensi tercetak tidak membutuhkan aplikasi apapun.

d. Kekurangan kamus online adalah belum mampu menerjemahkan kalimat atau teks bahasa dengan hasil terjemahan yang benar karena sering ditemukan kesalahan gramatika.

e. Bagi user atau penerjemah perlu skill operasionl system hardware dan koneksi internet dan harga perangkat atau kesempatan koneksi internet bagi banyak kalangan masih mahal dan sulit dalam mengaksesnya.

f. Ketergantungan akan sumber daya listrik

g. Ketergantungan akan sinyal dari provider provider penyedia jasa telekomunikasi.

h. Buka dan tutup aplikasi koleksi referensi online perlu waktu, untuk menghidupkan gadget menjalankan sistem operasi, menjalankan aplikasi membutuhkan waktu / loading yang cukup lama. 
Menurut pendapat Nesi dalam Winkler mengenai kamus digital $^{13}$

"However, none of the electronic dictionaries available at present is "ideal" in design and presentation of information. This is also true for the dictionaries on CD-ROM, whose integrated are not always compatible and exploit neither the storage capacity of the CD-ROM nor multimedia. Their games and exercises also seem to lack pedagogical reasoning. The major disadvantage of dictionaries on CD-ROM is, however, their site- dependency. A dictionary that can only be accessed via a desk-top computer is not really suitable for receptive purposes such as reading print and listening to lectures. Nevertheless, such a dictionary may be convenient for the learner who wants to look up words while writing a text with a word-processor. However, CD-ROMs and $C D-R O M$ drives are still fairly expensive and relatively fragile, which is something that not only the individual learner but also teachers and language teaching institutions will need to consider when purchasing a dictionary on CD-ROM".

"Namun, tidak satupun dari kamus elektronik yang tersedia saat ini adalah «ideal» dalam desain dan penyajian informasinya. Hal ini juga berlaku untuk kamus pada CD-ROM, yang terintegrasi tidak selalu kompatibel dan tidak mengeksploitasi kapasitas penyimpanan CD-ROM atau multimedia. permainan dan latihan mereka juga tampaknya kurang penalaran pedagogis. Kerugian utama dari kamus CD-ROM, bagaimanapun, ketergantungan situs- mereka. Sebuah kamus yang hanya dapat diakses melalui desktop komputer, tidak benar-benar cocok untuk tujuan menerima seperti membaca cetak dan mendengarkan ceramah. Namun demikian, kamus tersebut mungkin mudah bagi pelajar yang ingin mencari kata-kata saat menulis teks dengan pengolah kata. Namun, CD-ROM dan CD-ROM drive masih cukup mahal dan relatif rapuh, yang merupakan sesuatu yang tidak hanya pelajar saja tetapi juga guru dan lembaga pengajaran bahasa akan perlu mempertimbangkan ketika membeli kamus pada CD-ROM."

\section{Upaya Melestarikan Pemanfaatan Koleksi Referensi Cetak Oleh Perpustakaan Dan Dosen}

Perpustakaan merupakan media pengembangan minat baca untuk meningkatkan fungsinya untuk ikut berperanserta dalam pengembangan diri dari pemustaka. Salah satu faktor yang harus

13 Winkler, Birgit. 2001. English Learner's Dictionaries on CD ROM as Reference Language and Learning Tools. Journal Cambridge 13(2) : 192. 
dipenuhi untuk meningkatkan minat baca pemustaka di perpustakaan adalah koleksi yang lengkap dan dikelola dengan baik oleh pustakawan seperti yang tertuang dalam Undang-undang Republik Indonesia Nomor 43 tahun 2007 tentang Perpustakaan yang menyatakan bahwa koleksi perpustakaan diseleksi, diolah, disimpan, dilayankan, dan dikembangkan sesuai dengan kepentingan pemustaka dengan memperhatikan perkembangan teknologi infomasi dan komunikasi. ${ }^{14}$

Perpustakaan juga disebut berfungsi sebagai pusat sumber informasi di sini karena memang memenuhi ciri ciri antara lain: 1. Tempat dihimpunnya segala macam sumber informasi, baik dalam bentuknya yang tercetak maupun dalam bahan yang bukan hasil cetakan. 2. Tempat diolahnya bermacam ragam sumber informasi baik yang tercetak, maupun dalam bentuk rekaman elektronik ${ }^{15}$. Dari hal tersebut di atas sudah terlihat jelas bahwa perpustakaan memang harus melestarikan koleksi koleksinya baik koleksi dalam bentuk cetakan maupun non cetakan, termasuk dalam hal ini koleksi referensi tercetak. Hal lain yang harus menjadi perhatian adalah minat baca, minat baca bagi mahasiswa sampai saat ini masih rendah meskipun koleksi buku, jurnal, majalah ilmiah, koleksi digital dan terbitan lainnya yang dimiliki perpustakaan sudah cukup bagus. Bukan hanya mahasiswa tetapi dosen pun jarang ke perpustakaan dikarenakan banyaknya beban kerja mengajar kepada mereka terlalu banyak apalagi ditambah dengan kemudahan kecepatan penemuan informasi melalui media online semakin membuat mahasiswa dan dosen malas dalam menggunakan koleksi cetak dan khususnya koleksi referensi tercetak.

Beberapa strategi dapat dilakukan agar budaya menggunakan koleksi referensi tercetak dapat tetap dilestarikan dan tidak tergusur oleh kemunculan dari media referensi online seperti halnya di bawah ini:

1. Dengan menggalang kerjasama antara pustakawan dengan dosen dari semua jurusan ataupun program studi. Semisal :

${ }^{14}$ Undang-undang Republik Indonesia Nomor 43 tahun 2007 tentang Perpustakaan pasal 12 ayat 1 .

15 Yusup, M. Pawit. Teori dan Praktik Penelusuran Informasi : Information Retrieval. Jakarta : Kencana Prenada Media Group, 2010. Hlm. 16. 
a. Memberikan tugas untuk mencari informasi referensi di perpustakaan berkaitan dengan mata kuliah yang diampu.

b. Mengajarkan kompetensi minat baca mahasiswa dengan menerangkan cara menelusur informasi referensi pada koleksi buku.

c. Dapat juga dilakukan dengan memberikan tugas sebagai contoh dalam hal ini penulis selaku dosen juruan ilmu perpustakaan memberikan tugas kepada mahasiswa untuk mengevaluasi koleksi referensi tercetak serta memberikan presentasi bagaimana menemukan sebuah informasi dari kamus, direktori dan koleksi referensi tercetak yang lain.

d. Dosen memberikan kesadaran mengenai pentingnya mengakses informasi secara manual melalui kamus, ensiklopedia, direktori maupun koleksi referensi yang lain dalam suatu proyek tugas dari dosen, dan dengan bantuan pemustaka referensi untuk mengakses informasi referensi di perpustakaan.

2. Menumbuhkan budaya minat baca buku buku umum, khususnya buku buku referensi di kalangan akademisi dengan menambah koleksi referensi yang terbaru dan mutakhir demi meningkatkan koleksi buku yang ada di perpustakaan. Jadi perpustakaan perguruan tinggi lebih fokus dalam penyediaan bermacam informasi yang bersifat akademik ilmiah juga untuk menunjang kegiatan penelitian. Dalam menumbuhkan budaya baca yang perlus diperhatikan adalah mendorong bangkitnya minat baca masyarakat. Faktor-faktor membangkitkan minat baca masyarakat yaitu:

a. Rasa ingin tahu yang tinggi atas fakta, teori, prinsip, pengetahuan, dan informasi.

b. Keadaan lingkungan fisik yang memadai seperti tersedianya koleksi bacaan yang menarik, berkualitas dan beragam.

c. Rasa haus akan informasi, rasa ingin tahu terutama yang aktual. $^{16}$

16 Sutarno NS. Perpustakaan dan masyarakat. Jakarta: CV. Sagung Seto, 2006. 
3. Juga ada langkah langkah meningkatkan dan melestarikan budaya minat baca koleksi referensi seperti yang diungkapkan oleh Rahayuningsih dengan bimbingan penggunaan koleksi referensi. ${ }^{17}$ Bimbingan penggunaan koleksi referensi adalah bimbingan kepada pengguna agar mampu menggunakan koleksi dan sumber sumber informasi dengan tepat dan cepat. Bimbingan ini terdiri dari dua macam bimbingan yaitu bimbingan langsung dan tidak langsung. Bimbingan langsung terdiri dari bimbingan yang bersifat individual dan bersifat klasikal/formal sedangkan bimbingan tidak langsung diberikan melalui media tertentu antara lain : penerbitan buku informasi, buku pegangan, dan lain lain.

4. Dengan promosi koleksi referensi.

Menurut Lasa promosi yaitu menarik perhatian, minat atau mempengaruhi untuk menerima sebuah ide, konsep atau barang yang dipromosikan. ${ }^{18}$ Promosi koleksi referensi merupakan salah satu cara untuk menginformasikan koleksi referensi kepada pengguna agar koleksi referensi tersebut dikenal oleh para pengguna, sehingga daya guna dan keterpakaiannya semakin tinggi. ${ }^{19}$ Tujuan promosi koleksi referensi merupakan tujuan pembelajaran bagi pemustaka dalam mencari sebuah informasi yang dibutuhkan. Langkah langkah promosi referensi di antaranya :

a. Sosialisasi kepada pemustaka dalam penggunaan layanan referensi di perpustakaan.

b. Menginformasikan koleksi-koleksi referensi yang dimiliki oleh perpustakaan serta memberikan penekanan mengenai pentingnya mengetahui bagaimana memanfaatkan koleksi referensi tercetak secara mandiri

17 Rahayuningsih. Pengelolaan Perpustakaan. Yogyakarta : Graha Ilmu 2007. Hlm. 112.

18 Lasa. Kamus kepustakawanan indonesia. Pustaka book publisher: Yogyakarta, 2009. Hlm. 290

19 Rahayuningsih. Pengelolaan Perpustakaan. Yogyakarta : Graha Ilmu 2007. Hlm. 113-114. 
c. Melakukan bimbingan penelusuran informasi koleksi kepada pemustaka dalam mencari informasi.

d. Menambah koleksi referensi dan menginformasikan koleksi terbaru referensi melalui papan pengumuman/majalah dinding, pamflet, display/pameran maupun banner.

e. Mengadakan berbagai lomba yang berkaitan dengan wawasan atau pengetahuan mengenai koleksi referensi tercetak disertai penggunaannya.

\section{Simpulan}

Pada dasarnya menemukan informasi tertentu memang membutuhkan bantuan dari koleksi referensi yang telah tersedia dalam bentuk tercetak maupun versi onlinenya. Setiap orang dapat memilih yang mana yang akan dipakainya namun yang pasti setiap cara menemukan informasi melalui koleksi referensi tidak terlepas dari kemudahan dan kesulitan yang terjadi pada saat mengakses masing masing jenis koleksi baik yang tercetak maupun dalam versi online nya.

Perjalanan mencari informasi yang memerlukan bantuan koleksi referensi bagi sebagian orang mempunyai seni tersendiri misalnya dalam menemukan arti kata menggunakan kamus tercetak, ada kepuasan dan kesan tersendiri walaupun harus membolak balik halaman kamus namun bagi sebagian orang yang lain akan lebih efisien apabila menggunakan kamus online karena dinilai lebih cepat dan tepat. Kemudahan kemudahan yang ditawarkan oleh media referensi online yang semakin hari semakin dirasakan lengkap dan mampu memenuhi kebutuhan kita dalam menemukan informasi yang kita cari tanpa harus mengeluarkan banyak waktu dan tenaga, membuat kita harus berpikir bahwa pada suatu saat akankah nanti generasi mendatang kita tidak akan mengenal, kamus, direktori, peta, ensiklopedia dan media referensi tercetak lainnya, mereka tidak akan mau melirik bahkan menggunakannya dalam kehidupan mereka, akankah mereka lebih senang, nyaman dan puas dengan mengakses informasi informasi memakai bantuan dari produk produk media referensi online dengan segala kemudahannya. 
Bagaimana kita sebagai pustakawan sekaligus sebagai pendidik mencermati hal ini, pada keseharian mungkin kita juga lebih memanfaatkan media referensi online dibanding harus membolak balik halaman kamus, ensiklopedia, direktori, peta dan yang lain, namun dengan penuh kesadaran kita harus dapat menularkan keinginan dan kemampuan kita kepada siapapun untuk tetap terus melestarikan budaya mencari informasi dengan koleksi referensi tercetak agar karya karya ini tetap dikenal oleh generasi mendatang. 


\section{DAFTAR PUSTAKA}

Departemen Pendidikan Nasional. Kamus Besar Bahasa Indonesia Pusat Bahasa. PT. Gramedia Pustaka Utama: Jakarta, 2008.

Indonesia, Perpustakaan Nasional. Undang-undang Republik Indonesia Nomor 43 Tahun 2007 tentang Perpustakaan. Jakarta: Perpustakaan Nasional RI, 2007.

Lasa Hs. Kamus Kepustakawanan Indonesia. Yogyakarta: Pustaka Book Publisher, 2009.

Rahayuningsih, F. Pengelolaan Perpustakaan. Yogyakarta: Graha Ilmu, 2007.

Saleh, Abdul Rahman. dan Mustafa, Badollahi. Bahan Ruukan. Jakarta: Univeritas Terbuka. 2010.

Sutarno NS. Perpustakaan dan masyarakat. Jakarta: CV. Sagung Seto, 2006.

Suwarno, Wiji. Perpustakaan \& Buku: Wacana Penulisan \& Penerbitan. Jogjakarta: Ar-Ruzz Media, 2011.

Winkler, Birgit. English Learner's Dictionaries on CD ROM as Reference Language and Learning Tools. Journal Cambridge 13(2), 2001.

Yusuf, pawit M. Pedoman Praktis Mencari Informasi. Bandung: PT Remaja Rosdakarya, 1995.

Teori dan Praktik Penelusuran Informasi : Information Retrieval. Jakarta : Kencana Prenada Media Group, 2010. 
